\title{
髄液中神経伝達物質，アミノ酸およびフリーラジカル関連物質の 脸血管障害患者における変化
}

江頭 亭 ${ }^{1} \quad$ 後藤 浩 ${ }^{2)}$ 武田 弘志 ${ }^{3)}$ 高田 $\quad$ 香 $^{3)}$ 松宮 輝彦 ${ }^{3)}$

\begin{abstract}
〈要 約〉 老年期の脳血管障害者の髄液を用い，髄液中の神経伝達関連物質，アミノ酸およびラジカル関 連物質を同時に測定し, 老齢者と老年期の脳血管障害患者の髄液中のこれら生化学的マーカーの変化を比較 検討した。

Acetylcholinesterase（AChE）活性は老齢者対照者に比較して，脳血管障害者で低值を示したが，特に C 群（脳梗塞後遺症および脳出血後遺症の患者で, 長谷川式簡易知能評価スケールで比較的低值を示した者） で著明であった。一方, choline 含量は, 脳血管障害者で増加傾向を示した. 䯣液中のアミノ酸含量は, 脳 血管障害者で alanine の増加傾向を, glycine および glutamateの低下傾向が見られたが, 脳血管障害者群 間では有意な差はなかった。髄液中の epinephrine（E), norepinephrine（NE）および3-methoxy-4-hydroxyphenylethylene glycol (MHPG) 含量には有意な変化は認められなかったが, 5-hydroxyindole acetic acid （5-HIAA）および homovanillic acid（HVA）含量は老齢者対照群に比べ脳血管障害で低下傾向が， dihydroxyphenyl acetic acid（DOPAC）量では増加傾向が見られた。老化と関係が深いと考えられている superoxide dismutase（SOD）様活性は老齢者対照群と脳血管障害者間および脳血管障害者群間では有意差は見 られなかった。これらの測定結果は, 老齢者および老年期の脳血管障害による脳機能低下の病態の把握に有 用である.
\end{abstract}

Key words：䯣液，脳血管障害，アミノ酸，神経伝達物質，スーパーオキシドジスムターゼ

（日老医誌 $1999 ； 36 ： 256-261)$

\section{緒言}

脳血管障害, 特に脳梗塞患者における脳機能の回復は, その後の運動機能回復に繋がる重要な問題である.また, 老年期における脳血管障害は老年期痴呆疾患への移行の 可能性が充分推察される.このような脳血管障害に伴う 意欲低下, 精神障害などの精神症状の発現に中枢神経系 の各種神経伝達物質の量的異常やこれらの物質の合成 · 代謝酵素活性の異常が関与すると考えられている ${ }^{11}$. そ こで脳機能を神経生化学的に反映すると考えられる髄液 中の神経化学的マーカーを測定し, それらの物質の変動 の意義を評価する事は, 脳機能回復のためのより有効な 治療に寄与できるものと推察される。これまで老年期の 脳血管障害患者の髄液をもちいて, 神経伝達関連物質で ある acetylcholine (以下 ACh) ${ }^{2)}$, choline $e^{3)}$, G4型 Acetylcholinesterase (以下 $\mathrm{AChE})^{4)}$ ，モノアミンおよびそ の代謝物 ${ }^{5)}$ ，カテコールアミン関連醐素(6)，アミノ酸含

1) T. Egashira: 大分医科大学薬理学教室

2) H. Goto：湯布院厚生年金病院理学療法科

3) H. Takeda, K. Takada, T. Matsumiya : 東京医科大学 薬理学教室

受付日：1998.9.28, 採用日：1998.11.13
量》の各々についての報告は多い。しかし，これらの物 質および老化に関与したラジカル関連物質を同時に測定 した報告はない。

今回，中枢神経系のコリン作動性神経系に関係する $\mathrm{AChE}$ 活性扔よび choline 含量, アドレナリン, ドーパ ミンおよびセロトニン作動性神経系に関与する norepinephrine (以下 NE), epinephrine (以下 E), 3-methoxy4-hydroxy phenylethylene glycol (以下 MHPG), dihydroxy phenyl acetic acid (以下 DOPAC), homovanillic acid (以下 HVA), 5-hydroxyindole acetic acid (以下5HIAA）含量, アミノ酸として glutamate, arginine, alanine, threonine, taurine, glycine 含量および老化に関 与しているラジカル関連物質として superoxide dismutase（以下 SOD）活性を同時に測定し，老齢者と老年 期の脳血管障害患者における変化を比較検討した。

これらの髄液中の物質や酵素活性を測定することによ り, 脳血管障害による脳機能低下の病態を把握し, 治療 や予後の推定に役立てることができるものと思われる.

\section{方法}

（1）対象：脳卒中発作後 2 力月上上経過し, 症状が安 定している脳梗塞後遺症および脳出血後遺症の患者, 平 
均年齢66歳（54～89歳）を対象とした．非脳血管障害患 者として, 変形性膝関節症患者, 平均年齢70歳（52～83 歳）を対象とした.

以上の患者を以下の 4 群に分けた.

対照群 : 非脳血管障害患者（14名，長谷川式簡易知能 評価スケールでスコア $26 〜 30)$

$\mathrm{A}$ 群 : 脳出血後遺症患者 (17名, 長谷川式簡易知能 評価スケールでスコア21〜28)

$\mathrm{B}$ 群：脳梗塞後遺症患者（12名，長谷川式簡易知能評 価スケールでスコア22〜29)

$\mathrm{C}$ 群 : 脳梗塞後遺症および脳出血後遺症の患者で, 長 谷川式簡易知能評価スケールで比較的低值を示した者 $(7$ 名，スコア11〜19)

髄液試料：髄液採取に先立ち, 担当医が研究の主旨を 十分説明し，協力を依頼後，承諾を得られた患者の髄液 を用いた．髄液は腰椎穿刺を施行して $3.0 \mathrm{~m} l$ 採取し，た だちに液体窒素にて凍結, 測定まで $-80^{\circ} \mathrm{C} て ゙$ 保存した。

(2) モノアミンおよびその代謝物の測定：髄液 $10 \mu l$ を酸化還元スクリーン検出モードを導入した多重クーロ メトリー高速液体クロマトグラフィーシステムに直接注 入し, E, NE, MHPG, DOPAC, HVA, 5-HIAA 量を同時 測定した ${ }^{8)}$.

（3）AChE 活性：AChE 活性は Ellman ら9による分

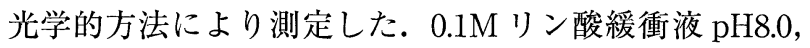
$0.01 \mathrm{M}$ dithio bisnitro-benzoate (DTNB)，髄液および 0.75 $\mathrm{M}$ acetylthiocholine iodide を加え $37^{\circ} \mathrm{C} て ゙ 反$ 応により産生 される5-thio-2-nitrobenzoic acid 量を分光光度計を用い, $412 \mathrm{~nm}$ の吸光度の変化を経時的に測定した．酵素活性 は5-thio-2-nitro benzoic acid 生成量 $(\mathrm{mU} / \mathrm{ml})$ で表した.

（4） choline 含量測定：髄液に0.2M perchloric acid を 加えて遠心分離し，除蛋白した。これに0.2M $\mathrm{KHCO}_{3}$ を 加えて中和し，0.5mm のフィルターを通した滤過液を 高速液体クロマトグラフー電気化学検出器を備えたエイ コム社製コリン，アセチルコリン分析システム BAC300 に注入し choline 量を測定した。

（5）アミノ酸測定：髄液 $100 \mu l$ を用い, 全自動高速液 体クロマトグラフィーを用いたアミノ酸分析装置（JLC300, 日本電子) で測定した。

（6）SOD 測定：ヒポキサンチンーキサンチンオキシ ダーゼ系で $\mathrm{O}_{2}^{-} を$ 発生させ，スピントラップ剂 $5,5^{\prime}-$ dimethyl-1-pyrroline-N-oxide（DMPO）を用いたスピン トラップ法により, DMPO-OOH アダクトに変えた。こ のシグナルを電子スピン共鳴装置分光光度計 (ESR 装 置, JES-RE1X, 日本電子) にて測定した. この発生系 にSOD 標品または髄液を添加することで, 定量化およ

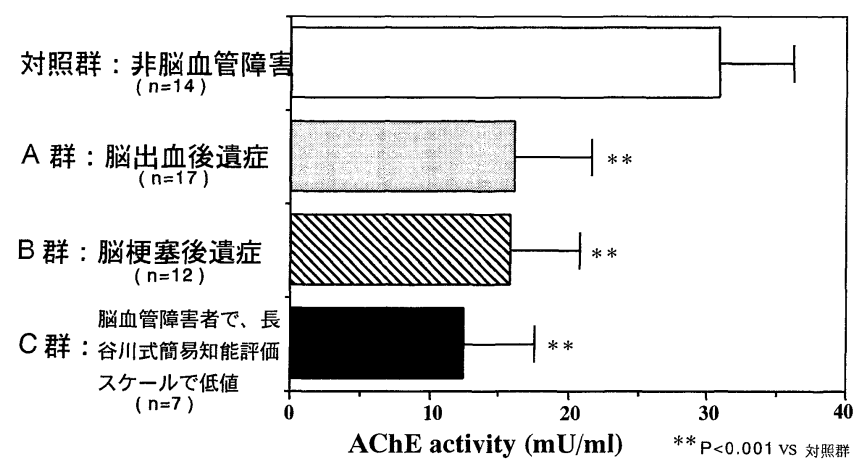

Fig. 1 髄液中の Acetylcholinesterase（AChE）活性

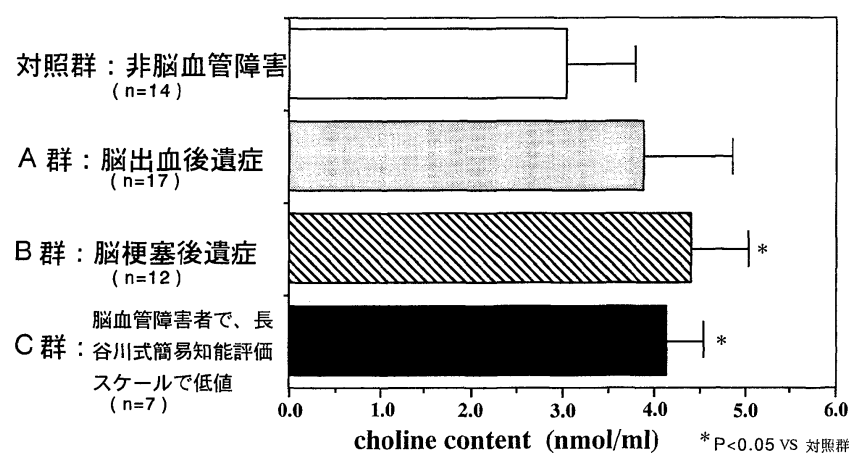

Fig. 2 髄液中の choline 含量

び含量を測定した ${ }^{10)}$.

（7）有意差検定

それぞれの測定結果は平均值士標準偏差（mean $\pm \mathrm{S}$. D.)で示した. また, 群間の有意差検定は Student's t-test およびWilcoxon 1 sample を用い，危険率 $5 \%$ 未満 $(\mathrm{p}<$ 0.05）を有意差あり，P<0.1を傾向として表記した.

\section{結果}

（1）コリン作動性神経系の生化学的マーカーの変動

老齢対照者の髄液中の $\mathrm{AChE}$ 活性は $30.5 \pm 5.6 \mathrm{mU} / \mathrm{ml}$ であった. 一方, 脳血管障害者群では老齢対照者に比較 して, 有意に低下し, A 群では $16.1 \pm 5.4 \mathrm{mU} / \mathrm{m} l, \mathrm{~B}$ 群で は $16.0 \pm 4.8 \mathrm{mU} / \mathrm{ml}$ であった. 特に長谷川式簡易知能評 価スケールで比較的低值を示したC 群では髄液中 $\mathrm{AChE}$ 活性の著明な減少が見られた（図1）。一方，中枢 では ACh の合成に使われ, ACh の分解で生じる choline 含量を髄液中で測定したところ，老齢対照者で $3.0 \pm 0.7$ $\mathrm{nmol} / \mathrm{ml}$ であった. 老齢対照者と比較して脳血管障害 者の $\mathrm{A}$ 群では有意差は認められなかったが, 脳血管障 害者の B および C 群では有意に増加していた（図2）。 しかし, 脳血管障害者間では有意差は認められなかった。

(2) 髄液中のアミノ酸含量 
表 1 髄液中のアミノ酸含量

\begin{tabular}{l|c|c|c|c}
\hline & $\begin{array}{c}\text { 老齢対照群 } \\
(\mathrm{n}=14)\end{array}$ & $\begin{array}{c}\mathrm{A} \text { 群 } \\
(\mathrm{n}=17)\end{array}$ & $\begin{array}{c}\mathrm{B} \text { 群 } \\
(\mathrm{n}=12)\end{array}$ & $\begin{array}{c}\mathrm{C} \text { 群 } \\
(\mathrm{n}=7)\end{array}$ \\
\hline Glycine & $7.36 \pm 2.70$ & $6.55 \pm 1.79^{\#}$ & $6.55 \pm 2.01^{\#}$ & $6.77 \pm 2.47^{\#}$ \\
Threonine & $31.05 \pm 10.26$ & $29.97 \pm 4.26$ & $28.43 \pm 6.28$ & $30.03 \pm 5.34$ \\
Alanine & $36.20 \pm 5.9$ & $37.65 \pm 10.35^{\#}$ & $38.55 \pm 8.56^{\#}$ & $39.79 \pm 10.14^{\#}$ \\
Taurine & $5.38 \pm 1.32$ & $6.43 \pm 1.60$ & $6.59 \pm 1.49$ & $5.77 \pm 1.94$ \\
Arginine & $20.83 \pm 3.94$ & $19.79 \pm 3.06$ & $22.11 \pm 3.61$ & $20.77 \pm 2.69$ \\
Glutamate & $752.2 \pm 97.8$ & $681.7 \pm 80.2^{\#}$ & $689.4 \pm 76.0^{\#}$ & $677.5 \pm 81.7^{\#}$ \\
\hline
\end{tabular}

\# p $<0.1$ vs 老齢対照群

髄液中のアミノ酸として glycine, threonine, alanine, taurine, arginine および glutamate 含量を測定し表 1 に 示した.アミノ酸含量は, 老齢対照者と脳血管障害者群 では有意な差は認められなかったが, 脳血管障害者で alanine 含量の増加傾向を, また, glycine および glutamate 含量の低下傾向が見られた. しかし, 脳血管障害 者間では有意差は見られなかった.

（3）髄液中のモノアミン類およびその関連代謝物含量 モノアミンのうち $\mathrm{E} ， \mathrm{NE}$ およびその代謝物である MHPG の髄液中含量を測定したところ, 老齢対照者で はそれぞれ $0.32 \pm 0.03 \mathrm{ng} / \mathrm{ml}, 0.61 \pm 0.26 \mathrm{ng} / \mathrm{ml}$ および 8.38 $\pm 1.05 \mathrm{ng} / \mathrm{ml}$ であった．脳血管障害者の $\mathrm{A}, \mathrm{B}$ および $\mathrm{C}$ 群で同様に $\mathrm{E}, \mathrm{NE}$ および $\mathrm{MHPG}$ 含量を測定したが，老 齢対照者との間には有意な差は認められなかった.また, 脳血管障害者間でも有意な変化は認められなかった. ドーパミンの代謝物である DOPAC および HVA 含量を

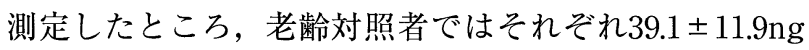
$/ \mathrm{m} l$ および $36.4 \pm 10.3 \mathrm{ng} / \mathrm{m} l$ であった. 同様に脳血管障 害者で測定したところ，老齢対照者に比較して有意差は なかったが，脳血管障害者で DOPAC 含量の増加傾向 が (A 群 : $63.07 \pm 28.27 \mathrm{ng} / \mathrm{ml}, \mathrm{B}$ 群 : $52.14 \pm 19.2 \mathrm{ng} / \mathrm{ml}$, $\mathrm{C}$ 群 : $53.55 \pm 10.3 \mathrm{ng} / \mathrm{ml})$, 脳血管障害者の A (30.3 \pm 9.9 $\mathrm{ng} / \mathrm{ml})$ およびC 群 $(23.7 \pm 10.9 \mathrm{ng} / \mathrm{ml})$ で HVA 含量 の低下傾向が見られた。一方，セロトニンの代謝物であ る5-HIAAの髄液中含量は老齢対照者で $22.5 \pm 7.4 \mathrm{ng} / \mathrm{ml}$ であった．脳血管障害者の5-HIAA の髄液中含量は老齢

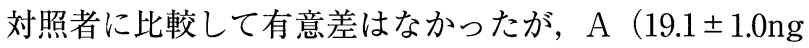

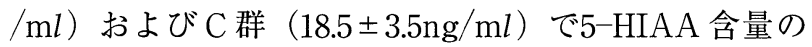
低下傾向が見られた。しかし，脳血管障害者間では有意 な変化は認められなかった。

（4）髄液中の SOD 活性

老化にフリーラジカルが深く関っている事が知られて いるが，そのフリーラジカルのうち活性酸素を消去する 酵素である SOD 様活性を, 活性酸素消去能から測定し

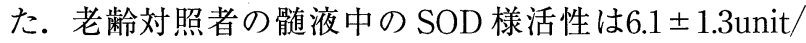
$\mathrm{m} l$ であった。老齢対照者と脳血管障害者群を比較した が，有意差はなく，また，老齢脳血管障害者間でも有意 差は見られなかった。

\section{考察}

髄液は脳の細胞外液とある部分共通の性質をもってい ると考えられている。すすおち神経伝達物質の放出や代 謝物の排出は脳局所細胞外液中へと移動し，これが髄液 へと流出してくる：このことから，髄液で神経伝達物質 やその代謝産物を測定し, その結果から脳機能を推定で きると考えられている。

コリン作動性神経系は, 学習・記憶との関わりから, 痴呆疾患では重要視されている ${ }^{11)}$ ACh や AChE は中 枢の神経細胞から分泌され, 髄液に移行することが実験 的にも証明されている 液中の濃度を脳血管障害患者で検討することは, 脳血管 障害による痴呆の早期診断, 早期治療に寄与するものと 思われる. 今回, 髄液中の ACh および choline 含量を 測定したが，AChはほとんど検出不可能であった. 脳 血管障害例において, 髄液中の $\mathrm{ACh}$ 濃度測定は重要で あるが, 現時点では困難であり, 採取方法や測定法の改 良が必要であろう。一方, choline 含量は老齢対照者に 比較して, 脳血管障害患者で有意に高值を示した。この 事は, 脳血管障害患者では, ACh の代謝が立進してい るか, または, cholineの再取り込みの低下が考えられ る. しかし, choline は食事やその他の生理的合成・代 謝系によりその濃度が維持される可能性が高いため, 䯣 液中の choline $\mathrm{ACh}$ の分解物としてのみ判断する事 はできない。これらの事より, 髄液中の ACh や choline 含量の変化を脳血管障害の指標とするには難点がある. 一方，髄液中の AChE 活性に関しては, Alzheimer 型 痴呆で G4型 AChE 活性の低下が, また, 脳血管性痴呆 や大梗塞でも低下傾向があるとの報告が多い4)，G4型 
$\mathrm{AChE}$ は AChE アイソザイムのうち，神経組織由来の もので, いわゆる真の $\mathrm{AChE}$ であり, コリン作動性神 経内で軸索流により運ばれ細胞外に分泌される．この事 から, 髄液中の $\mathrm{AChE}$ 活性の測定は, 脳のコリン作動 性神経機能の情報を得る手段として繁用されている4). 今回の成績でも，脳血管障害者は老龄対照者に比較して 有意に低值を示し，特に長谷川式簡易知能評価スケール で比較的低値を示した脳血管障害者でその低下が著明で あった.このことは, 脳血管障害の後遺症として, コリ ン作動性神経系が障害を受け，G4型 AChEの䯣液中へ の移行が減少したために活性低下が見られたものと思わ れる。

髄液中の遊離アミノ酸濃度の加齢変化や脳血管性痴 呆, Alzheimer 型痴呆での変化について有意に低下や増 加するとの報告があり，一定した報告は得られていない． この理由は不明であるが，脳血管性痴呆では血液脳関門 の機能低下や脳血管透過性の克進が報告されており，血 管からアミノ酸が髄液へ漏出した可能性も考えられてい る.しかし，今回我々が検討したアミノ酸類の髄液中濃 度は老齢対照者と脳血管障害者との間に有意な変化は認 められなかった。おそらく今回検討した脳血管障害者が それほど痴呆が進行していなかったためと思われる。し かし，老噛対照者との間に有意差は見られなかったが, alanine 值の増加傾向, glycine および glutamate 值の低 下傾向が見られた. alanine 值の増加傾向や glycine 值 の低下傾向の作用機序は不明であるが, glutamate 值に 関しては，若年者 ${ }^{133} に$ 比較して老齢者で，また，老齢対 照者に比較して老齢脳障害者で低值を示す事や，過剩の glutamate が細胞毒性作用を有することなどから，髄液 中の glutamate 值は老化のマーカーや脳血管障害のマー カーとなる可能性が考えられる.

髄液中のモノアミン類およびその代謝物濃度の低下は 脳血管障害においても中枢神経系ニューロンの機能低下 を反映するものと考えられる。しかし，アミノ酸含量の 場合と同様に一定した報告は得られていない(14)15). 今回, 著者らが脳血管障害者の髄液について検討した成績で は，E，NE およびその代謝物である MHPG は，老龄対 照者と脳血管障害者および脳血管障害者間では有意な変 化は認められなかった. ドーパミンの代謝物である DOPAC 含量は脳血管障害者で増加傾向に, HVA 含量 は低下傾向にあった。この事は，脳血管障害者における 脳内のドーパミンは MAO (Monoamine Oxidase) によ りDOPACに代謝される経を主に通るものとおもわれ る. 一方，5-HIAA 含量は脳血管障害者の一部で低下傾 向が見られた，今回の我々の成績では，モノアミン類の
代謝産物である HVA や5-HIAA の髄液中の含量は，脳 血管障害で低下する傾向を示した．しかし，前述の様に 施設により一定した結果が得られていないのが現状であ る。この理由として, 基礎的には, 血液中から䯣液への 混入の有無, 血液一脳一髄液関門が正常であるか否か, 髄液中の濃度勾配の問題 ${ }^{16)}$, さらに測定されたものが脊 䯣でなく脳に由来しているか否か，また，臨床的には， 神経症状の重症度との関係，すなわち脳血管障害の急性 期では髄液中モノアミン濃度は高值を示すがこれらの変 化はいつまで持続するか，また慢性期のモノアミンの動 態と臨床病態との関連性は，などが問題点として考えら れる。

近年，老化と SOD との関連性が注目されているがそ

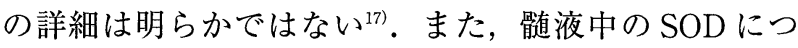
いての報告も少なく, 神経疾患の一部で髄液中の SOD 值が上昇することが報告されている ${ }^{18}$. 今回の我々の測 定で，老齢対照者の髄液中の SOD 様活性は $6.1 \pm 1.3$ unit $/ \mathrm{m} l$ であり，小児の髄夜の值 $(1.4 \pm 0.8 \mathrm{unit} / \mathrm{m} l)$ に比較 して著しい高值を示した。脳中の SOD 比活性は長寿な 高等動物ほど高い活性を示す事 ${ }^{19}$ から, 髄液中 SOD 様 活性の高值は，老化の指標とすることができる可能性を 持つ事を示唆している.しかし，老齢対照者と脳血管障 害者間では有意差はなく, 脳血管障害の重症度とは相関 しないものと思われる。

今回測定した髄液中の神経化学的マーカーは老化, 特 に老年期の脳血管障害（痴朵を含む）により，変化する との報告が多いものを選択したが，一部を除いて，変動 が著明でなかった。これは，今回対象とした脳血管障害 者が慢性の脳梗塞, 脳出血後遺症者であったこと, 痴呆 スコアの評価から障害が比較的軽症であったことからこ のような結果が得られたものと思われる。しかし，老齢 対照者に比較して脳血管障害者の髄液中の $\mathrm{AChE}$ 活性 の有意な低下, choline 含量の増加, モノアミン類では, 5-HIAA, HVA 含量の低下傾向, DOPAC 量の増加傾向, アミノ酸のうち alanine 含量の増加傾向, glycine およ び glutamate 含量の減少傾向が見られた。これらは，老 年期の脳血管障害のマーカーとして，基礎的に充分利用 出来る興味深い所見であり, 今後症例数を重ね, 検討を 要すると思われる.

謝辞：本研究に際し，多数のサンプルを提供して戴いた湯 布院厚生年金病院内科, 衛藤 宏先生に深謝いたします。

\section{文献}

1）中村重信, 亀山正邦: 老年痴呆における神経伝達物質. 精神科 MOOK No. 8 (島薗安雄, 保崎秀夫, 長谷川和夫 
編)，金原出版，東京， $1984 ;$ p $79-89$.

2）岩佐英明：脳血管性痴呆とアセチルコリン。臨床成人病 $1992 ; 22: 1432-1433$.

3）池田淑夫, 友田桂子, 大城公恵, 奥山真司, 藤木嘉明, 伊藤哲彦：アルツハイマー型痴呆における脳脊䯣液中ア セチルコリン動態と記憶機能．精神薬療基金研究年報 1991 ; 第22集, 1 - 6 .

4) Nakano S, Kato T, Nakamura S, Kameyama M : Acetylcholinesterase activity in cerebrospinal fluid of patients with Alzheimer's disease and senile dementia. J Neurol Sci $1986 ; 75: 213$ - 223 .

5）川上正人，伊東 亨：脳血管障害の知的機能低下例にお ける髄液中モノアミン代謝物質への CV-2619（イデベノ ン）錠の影響。脳神経 $1986 ; 38: 187-193$.

6) 宮田 学, 山尾 哲, 中村重信, 宇高不可思, 亀山正邦： 老年痴呆および多発梗塞痴呆における神経伝達物質の動 態. 臨床神経学 $1981 ; 21: 491-497$.

7) Togi H, Abe T, Hashiguchi K, Takahashi S, Nozaki Y, Kikuchi $\mathrm{T}$ : A significant reduction of putative transmitter amino acids in cerebrospinal fluid of patients with Parkinson's disease and spinocerebellar degeneration. Neurosci Lett $1991 ; 126: 155-158$.

8) Takeda H, Matsumiya $T$, Shibuya $T$ :Detection and identification modes for the highly sensitive and simultaneous determination of various biogenic amines by coulometric highperformance liquid chromatography. J Chromatogr 1990; 515:265-278.

9) Ellman GL, Courtney KD, Andres V. Jr, Featherstone $\mathrm{RM}$ : A new and rapid colorimetric determination of acetylcholinesterase activity. Biochem Pharmacol 1961;7: $88-95$.

10) Takayama F, Egashira T, Yamanaka Y : Effect of diclofe- nac, a non-steroidal anti-inflammatory drug, on lipid peroxidation caused by ischmeia-reperfusion in rat liver. Jpn J Pharmacol $1994 ; 64: 71-78$.

11）岩田 悟：髄液コリンエステラーゼと痴呆との関係につ いて．名市大医誌 $1988 ; 39: 301-329$.

12) Chubb IW, Goodman S, Smith AD:Is acetylcholinesterase secreted from central neurons into the cerebrospinal fluid? Neuroscience $1976 ; 1: 57-62$.

13）山田謙慈, 杉山一彦, 藤田浩史, 井上圭太郎：脳梗塞に おける髄液中神経伝達物質の变動に関する臨床的研究. IRYO 1992;46:592-602.

14）福田英俊, 中村重信, 原 健二, 宇高不可思, 亀山正邦： 各種神経疾患における䯣液5-hydroxyindoleacetic acid (5HIAA）濃度の検討. 臨床神経学 $1989 ; 29: 1192-1194$.

15) Wester P, Puu G, Reiz S, Winblad B, Wester PO:Increased monoamine metabolites and cholinesterase activities in cerebrospinal fluid of patients with acute stroke. Acta Neurol Scand $1987 ; 76: 473-479$.

16) Wood JH : Neurochemical analysis of cerebrospinal fluid. Neurology $1980 ; 30: 645-651$.

17) Harman $D$ : Free radical theory of aging: Role of free radicals in the organization and evolution of life, aging, and disease processes, In : Free Radicals, Aging and Degenerative Diseases, Johnson JE (ed), Alan R. Liss. Inc., New York. 1986 ; p. 3-49.

18) Marttila RJ, Vijanen M, Toivonen E, lorentz H, Rinne UK : Superoxide dismutase-like activity in the Parkinson's disease brain. Adv Neurol 1990; $53: 141-144$.

19) Tolmasoff JM, Ono T, Culter GR: Superoxide dismutase:Correlation with life-span and specific metabolic rate in primate species. Proc Natl Acad Sci USA 1980; $77: 2777-2781$ 


\title{
Abstract
}

\section{Alterrations in Neurotransmitter, Amino Acid and Free Radical Related Substances in Cerebrospinal Fluid in Patients with Cerebrovascular Diseases.}

\author{
Toru Egashira ${ }^{1)}$, Hiroshi Goto ${ }^{27}$, Hiroshi Takeda ${ }^{3)}$, Kaori Takada ${ }^{3)}$ and Teruhiko Matsumiya ${ }^{3)}$.
}

Acetylcholinesterase (AChE), choline, monoamine and its metabolite, amino acid and superoxide dismutase (SOD) levels were measured in cerebrospinal fluid (CSF) in patients with cerebrovascular diseases. Patients were classified into the following four groups; controls : normal subjects without neurological disease, group A : cerebral hemorrhage, group B: cerebral infarction, group C: patients with mental impairment, including those in groups A and B, and a low score on Hasegawa's Dementia Rating Scale. CSF AChE level of groups A, B and C was decreased significantly, while choline concentration from patients showed a increase compared with that of control cases. CSF alanine concentration showed a tendency to increase, while glycine and glutamate tended to decrease. CSF epinephrine, norepinephrine or 3-methoxy-4-hydroxyphenylethylen glycol concentrations of groups A, B and C did not exhibit a significant difference from that in control cases. Some cases with cerebrovascular diseases showed low concentrations of both CSF 5-hydroxyindole acetic acid and homovanillic acid. However, dihydroxyphenyl acetic acid concentration was higher than in control cases. The CSF SOD level was not significantly from that in control cases. The changes in neurochemical substances in the CSF support their use as markers of cerebrovascular disease-related change.

Key words : Cerebrospinal fluid, Cerebrovascular diseases, Amino acid, Neurotransmitter, Superoxide dismutase (Jpn J Geriat $1999 ; 36: 256-261$ )

\footnotetext{
${ }^{1)}$ Department of Pharmacology, Oita Medical University.

${ }^{2)}$ Department of Physiotherapy, Yufuin Koseinenkin Hospital

${ }^{3}$ Department of Pharmacology, Medical College of Tokyo
} 